\title{
EARLY WARNING OF LEAKING LPG GAS THROUGH SHORT MESSAGE SERVICE (SMS) AND LOUDSPEAKER TOOL USING ARDUINO UNO
}

\author{
Novi Rahayu \\ Sekolah Tinggi Ilmu Administrasi Bengkulu \\ novierahayu1980@gmail.com
}

\begin{abstract}
Currently, the function of Liquified Petroleum Gas (LPG) is very important for human life, both in the household and industry. However, this can have a negative impact, especially in terms of if there is no known leaky hole that can cause an explosion and fire. The main factors that can cause the leaking of gas cylinders include improper installation of regulators, poor quality of tube sealing rings, quality of gas cylinders, non-regulators of the Indonesian National Standard (SNI), tear gas hose due to animals such as mice. The way of working from these tools when the MQ-6 sensor detects LPG gas above 100 ppm, the sensor will send data to the microcontroller on Arduino Uno for giving a response as a buzzer as an alarm, the loudspeaker as gives notification the sound of danger and send information in the form of SMS to the home owner. The test results that this warning system can indicate if any leaking on the gas concentration of 117 to $457 \mathrm{ppm}$ and the duration of sending SMS between 3 to 182 seconds from five tests given in three different places.
\end{abstract}

Keywords: $L P G$, Arduino Uno, MQ-6 Sensor, SMS.

\section{INTRODUCTION}

This kerosene to LPG conversion program is carried out on the basis of Law No.22 of 2001 concerning Oil and Gas, Presidential Regulation No.5 of 2006 concerning National Energy Policy, Presidential Regulation No.104 of 2007 concerning Provision, Distribution, and LPG Price Determination of $3 \mathrm{Kg}$ Tubes, and Minister of Energy and Mineral Resources Regulation No.26 of 2009 concerning LPG Supply and Distribution. One of the major goals to be achieved is the realization of an optimal (primary) mix energy in 2025, namely the role of petroleum to be less than $20 \%$ and the role of natural gas to be more than $30 \%$ of national energy consumption. It is expected, the consumption of kerosene which was originally 9.9 kiloliters can go down to 2 kiloliters. The conversion target for the first stage is households and micro businesses that are still cooking with the help of kerosene and do not yet have a gas stove.

After more or less three years, the kerosene to LPG conversion program has gradually begun to show its success. Evita Legowo, Director General of Oil and Gas of the Ministry of Energy and Mineral Resources, said that in 2008, a year of the implementation of the current program, the budget saved was 5.53 trillion rupiah; in 2009 it saved 6.92 trillion rupiahs; in 2010 there were savings of 14.38 trillion rupiah. This amount is large enough to be allocated to other posts in the APBN. From the role of LPG gas at this time is very important for human life. But at the same time, behind the increasing use of LPG gas, various problems began to emerge. LPG gas has a negative impact on humans and can even lead to the potential for explosion and fire hazards.

Many factors can cause leakage of LPG gas cylinders, including improper installation of regulators, poor quality seal rings, non-tested Indonesian National Standard (SNI) regulators, gas hose tearing caused by animals such as rats, as well as the quality of the LPG cylinder itself which can unwittingly cause a gas leak. Given the considerable losses that can be caused from LPG gas leakage, the authors are interested in creating a system of "Early Warning LPG Gas Leaks Through Short Message Service (SMS) and Loudspeakers (Speakers) Using Arduino Uno".

\section{LITERATURE REVIEW}

Detection is a process to check or examine something using certain methods and techniques. The purpose of detection is to solve a problem by speaking depending on the method applied so as to produce a solution. 
LPG (Liquefied Petroleum Gas) LPG gas (Wiyono, et. al., 2017) is a gas fuel obtained from the high pressure distillation process. The fraction used as bait can come from several sources, namely from natural gas and gas from the processing of petroleum (Light End). Liquefied Petroleum Gas (LPG) consists of carbon and hydrogen elements which are hydrocarbon compounds with the main components $\mathrm{C} 3$ and $\mathrm{C} 4$. The LPG composition consists of propane $(\mathrm{C} 3 \mathrm{H} 8)$, propylene or propene $(\mathrm{C} 3 \mathrm{H} 6)$, butane $(\mathrm{C} 4 \mathrm{H} 10)$, butylene or butene $(\mathrm{C} 4 \mathrm{H} 8)$, and small amounts of ethane $(\mathrm{C} 2 \mathrm{H} 6)$, ethylene $(\mathrm{C} 2 \mathrm{H} 4)$, and penthana $(\mathrm{C} 5 \mathrm{H} 12)$.

The nature of LPG is mainly as follows :

1. The liquid and gas are very flammable

2. Gas is non-toxic, colorless and usually has a strong odor

3. Gas is sent as a liquid

4. Liquids can evaporate if released and spread quickly.

5. LPG gas is heavier than air so it will occupy a lot of low areas

Microcontroller, Microcontroller is widely available in all-electronic equipment, fax machines, and other electronic equipment. The microcontroller can also be called a small computer that is low-power so that a battery can provide power(Kadir, 2018).

Arduino (Fatoni \& Rendra, 2014) is an open-source single-board micro controller, derived from the Wiring platform, designed to facilitate the use of electronics in various fields. The hardware has the Atmel AVR processor and the software has its own programming language. Arduino UNO is a microcontroller board based on ATmega328 (datasheet).

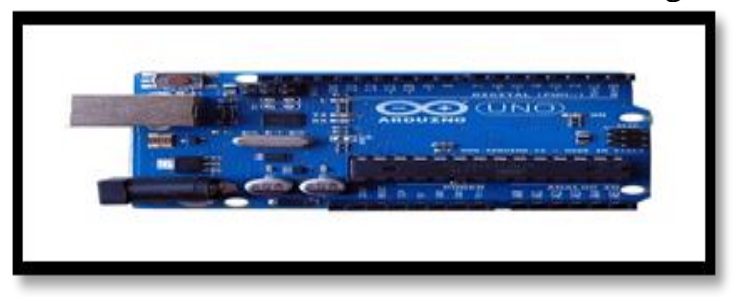

Figure 1. Arduino UNO

The MQ 6 sensor (Putra, et. al., 2017) is a gas sensor that is suitable for detecting LPG (Liquefied Petroleum Gas), can detect LPG gas and includes gases consisting of LPG gas namely propane and butane gas. This sensor can detect gases at concentrations in the air between 200 to $10000 \mathrm{ppm}$. This sensor has high sensitivity and fast response time. The sensor output is analog resistance. The circuit of this sensor is very simple, what this sensor needs is to provide a voltage of $5 \mathrm{~V}$, add load resistance, and connect the output to the ADC.

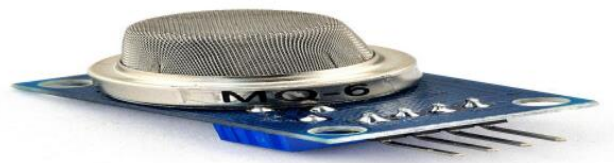

Figure 2. MQ-6 Gas Sensor

The ISD1820 module (Ohoiwutun, 2018) is a single chip module that functions as a voice recorder with a memory storage capacity of $3.2 \mathrm{~K}$ capable of recording a maximum of 20 seconds with direct output on 8 OHM speakers (recommends aasheet) or active speakers, and the working voltage is only $3.3 \mathrm{~V}$.

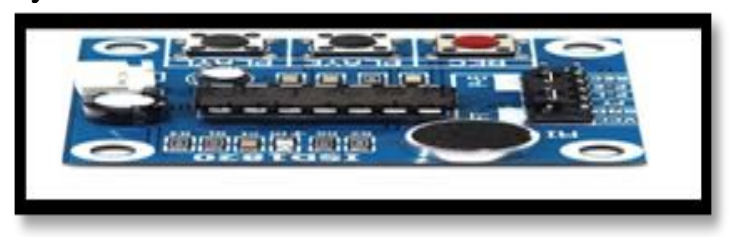

Figure 3. ISD1820

Arduino GSM Shield (Hakim \& Yonatan, 2017) is an additional component that allows Arduino to connect to the GSM network, send and receive voice, text and GPRS services. This 
component uses digital pins 2 and 3 for serial communication with the Arduino board and uses the M10 Quad-band GSM / GPRS radio modem from Quectel that supports 4 GSM $850 \mathrm{MHz}$ frequencies, GSM 900MHz, DCS $1800 \mathrm{MHz}$ and PCS $1900 \mathrm{MHz}$. With a maximum speed of GPRS data transfer $85.6 \mathrm{kbps}$.

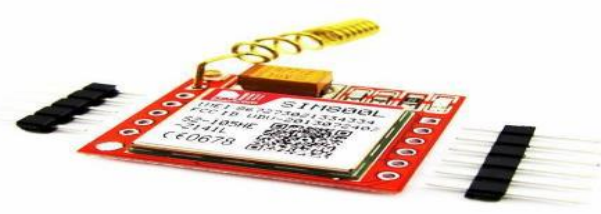

Figure 4. SIM800L GSM Module

Buzzer (Wiyono, et al., 2017) is an electronic component that functions to convert electrical vibrations into sound vibrations. The working principle of the buzzer is almost the same as the loudspeaker. A buzzer consists of a coil mounted on a diaphragm and flowed so that it becomes an electromagnet. The coil will be pulled in or out depending on the current direction and magnetic polarity. Because the coil is mounted on the diaphragm, each movement of the coil will move the diaphragm back and forth so that it makes the air vibrate and produce sound.

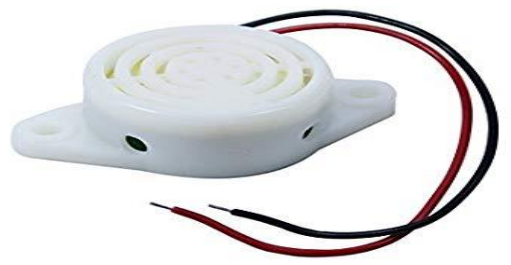

Figure 5. Buzzer

LCD (Liquid Crystal Display) (Wiyono, et al., 2017) is a media that uses liquid crystal as the main viewer. LCD has been used in various fields such as electronic devices such as televisions, calculators or computer screens. LCD functions to display writing in the form of numbers or letters in accordance with the wishes based on the program used, so that the display can be seen visually.

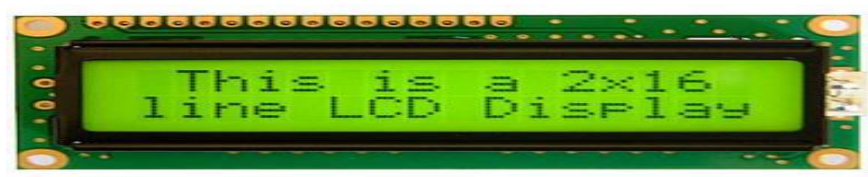

Figure 7. $16 \times 2$ LCD

\section{RESEARCH METHOD}

\section{Prototype}

Prototype is not something that is complete, but something that must be evaluated and modified again. All changes can occur when prototypes are made to meet user needs and at the same time allow developers to better understand user needs(Hendini, 2016). 


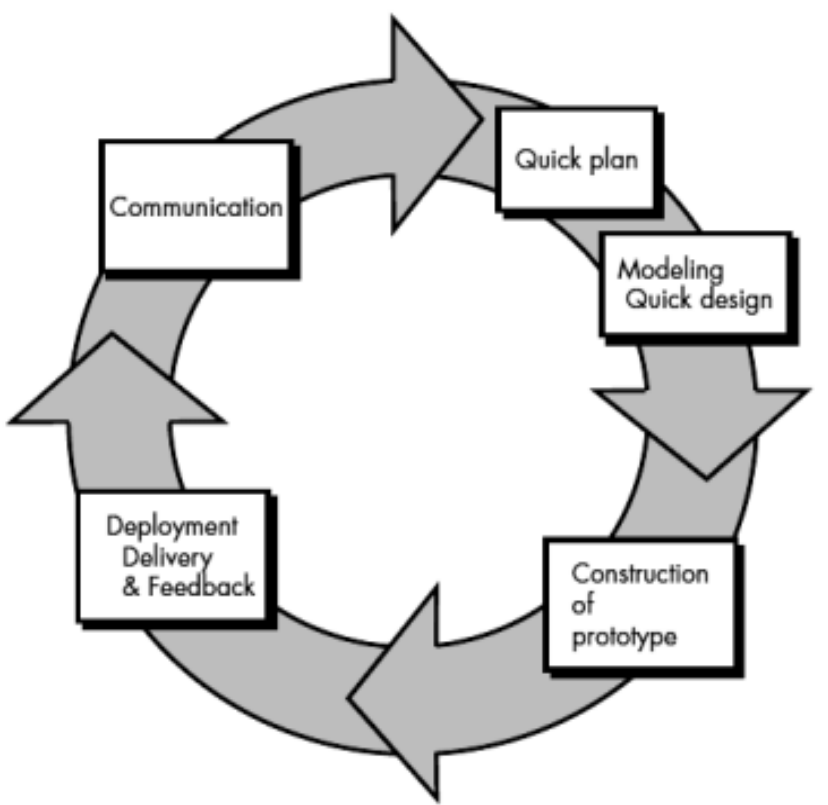

Figure 8. Prototype Paradigm

\section{Flowchart}

Flowchart is a graphical development of the steps and sequence of procedures of a program. Flowcharts help programmers to solve problems in smaller segments and help in analyzing other alternatives in operation.

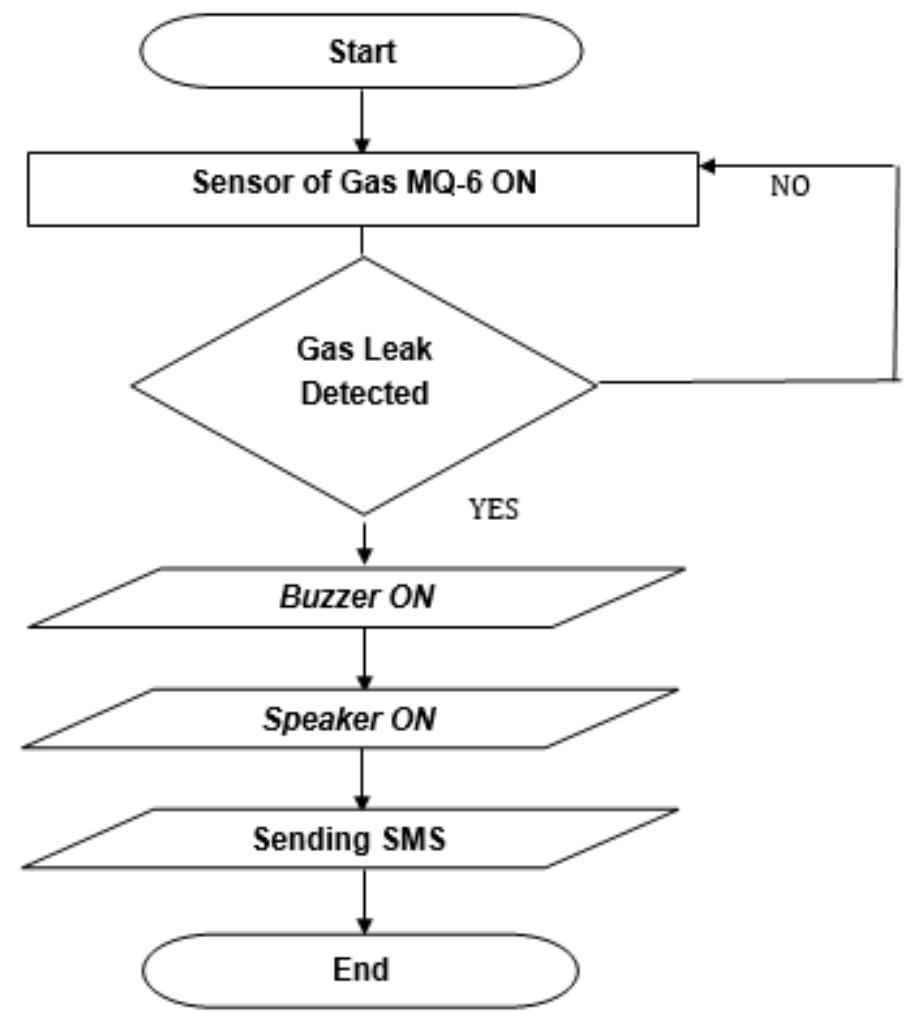

Figure 9. Flowchart Gas Leak Detection System

\section{RESEARCH RESULTS AND DISCUSSION \\ Design Interface}


Interface Design or more commonly known as Interface Design is a design for computers, equipment, machines, mobile communication devices, software applications, and websites that focus on the experience and interaction of its users.

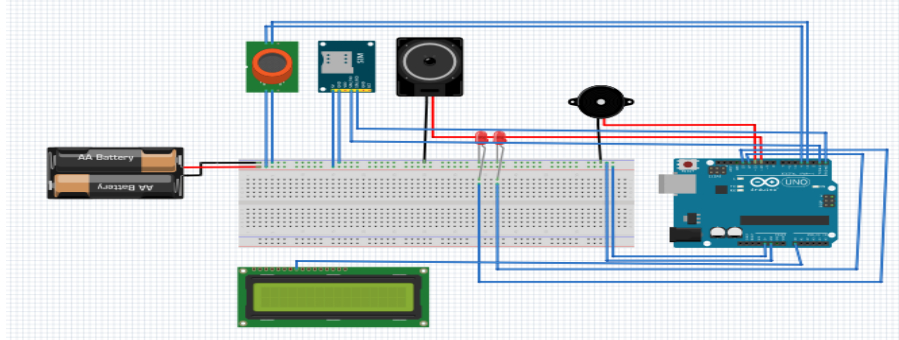

Figure 10. Design Interface for Gas Leak Detection System

\section{MQ-6 Sensor Testing Technique}

The MQ 6 sensor is a gas sensor that is suitable for detecting LPG (Liquefied Petroleum Gas), can detect LPG gas and includes gases consisting of LPG gas, namely propane and butane gas. This sensor can detect gases at concentrations in the air between 200 to $10000 \mathrm{ppm}$. This sensor has high sensitivity and fast response time. The sensor output is analog resistance. The circuit of this sensor is very simple, what this sensor needs is to provide a voltage of $5 \mathrm{~V}$, add load resistance, and connect the output to the ADC.

\section{Tool Design}

The making of this LPG gas leak detection system goes through several manufacturing stages. Starting with preparing the materials and tools used. Like setting up the box and compiling the arduino mainboard with arduino GSM shield, buzzer and speaker. The purpose of making a box is to place the input and output components or as a container of the system this tool can facilitate and adjust the system in its use. The next process is the electronic schematic assembly of a gas leak detection system.

\section{Making Circuits}

At the stage of making this circuit, what is done is to prepare components that will be used, such as the mq-6 sensor, Arduino Uno, relay, step down, adapter, power / battery, GSM SIM800L, buzzer, ISD1820 module, speaker and jumper cable. The arduino uno has an Atmega 328 microcontroller, which has 14 digital input / output pins (6 outputs for PWM), and 6 analog input pins. Arduino electronic circuits have several other components such as IC regulators that function as the power supply circuit needs. As a source of voltage in this circuit using a 12 volt adapter. For the MQ-6 sensor circuit, get an electrical input of $5 \mathrm{~V}$ and use a $5 \mathrm{~V}$ pin to provide input to the microcontroller / arduino, the buzzer uses pin D11 to output, the led pins D12, D13 and SMS are connected with pin A0, while for The speaker is connected directly to the MQ-6 gas sensor on the DO pin(Elasya, 2016).

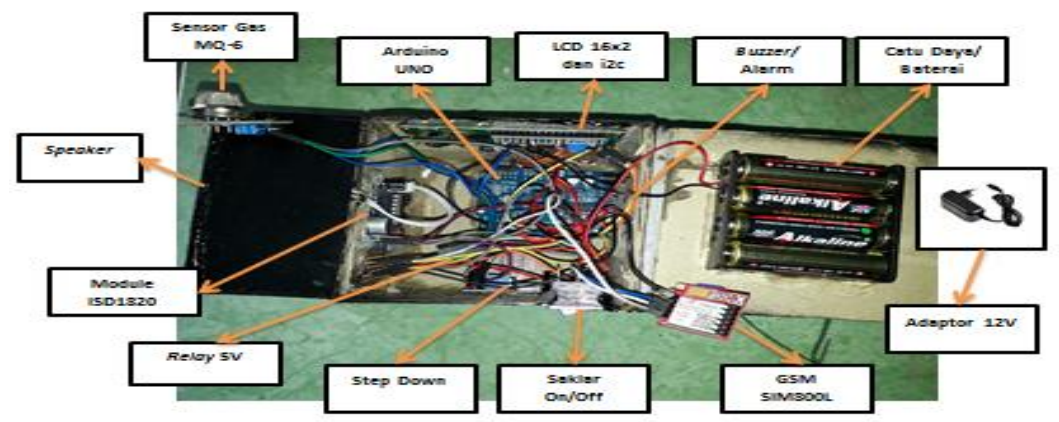

Figure 11. Series of Gas Leak Detection Devices

\section{Program Design}

The design of the gas leak detection system program consists of several stages. The first process is the making of a flowchart of the gas leak detection system, then the program is made 
using the Arduino IDE using $\mathrm{C}$ language and this program will execute commands on the system and tools. Then the program has been uploaded to the microcontroller using Arduino IDE. Furthermore, the microcontroller will perform the process of reading the condition of the gas sensor. If it detects a gas leak, the red LED will light up, the alarm will be active, and will automatically text the homeowner. If the sensor does not detect the gas, the system will continue to read the condition of the sensor until it detects leaked gas again.

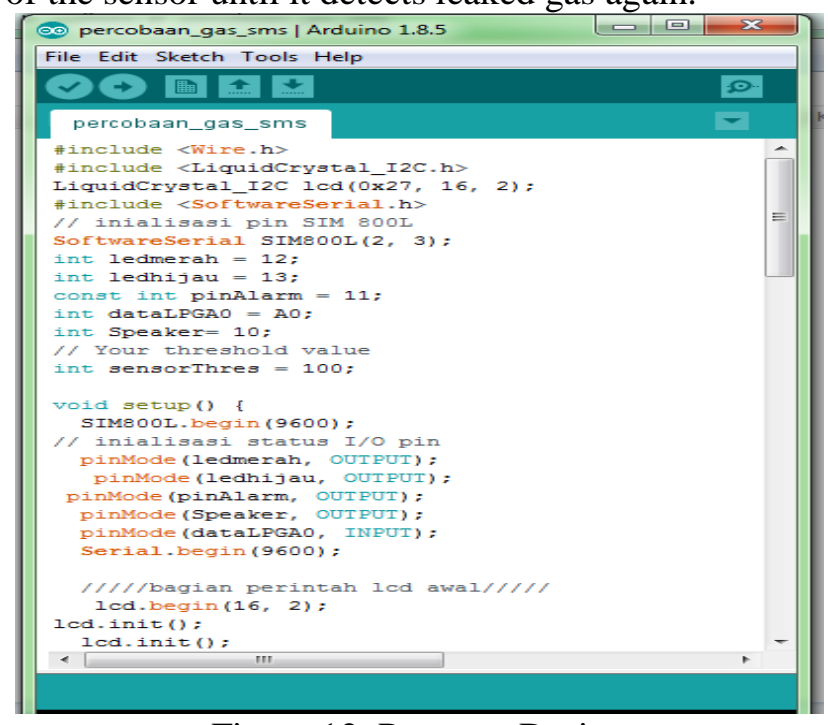

Figure 12. Program Design

\section{Implementation}

After the system is built based on the designs that have been made, the next step is to upload the program. Connect the USB cable with the Arduino Uno board and on the other side is connected to the computer. Open the Arduino IDE program then open the sketch program that has been created, then press the upload button on the Arduino IDE so that the sketch is transferred from the computer to the Arduino board. After completing the upload, the USB cable can be removed and the gas leak detection system can work without the help of a computer again.

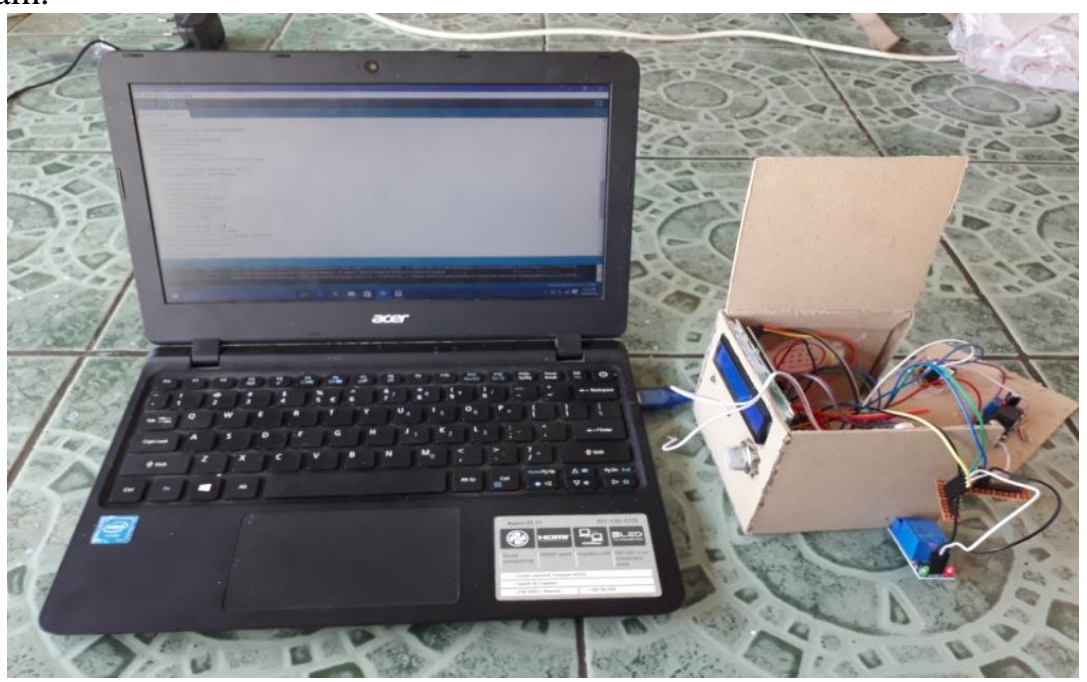

Figure 13. The Arduino IDE Program Upload Process

In this last stage all components are well connected and have a program inside the microcontroller. This test is carried out using a simulation display using a gas lighter to activate the MQ-6 sensor in detecting gas. The way this device works is by connecting to a battery power source or using a 12 volt adapter and pressing the ON / OFF button located on the right side of the box. On a system device to turn on the system is indicated by a green LED light. If the initial steps for testing the system have been carried out then the operation can be carried 
out, the order of which is the detection of the Propane gas sensor. As the main component of the microcontroller works by running the commands that have been inputted in the form of coding, where the coding represents the command to run the MQ-6 sensor, led lights, buzzer, Speaker and SMS. So as to produce some output in the form of a gas sensor detects propane gas, the buzzer will turn on, the speaker will turn on, and send information in the form of SMS to the homeowner. This device testing simulation aims to see whether the sensor, microcontroller and the program are running well.

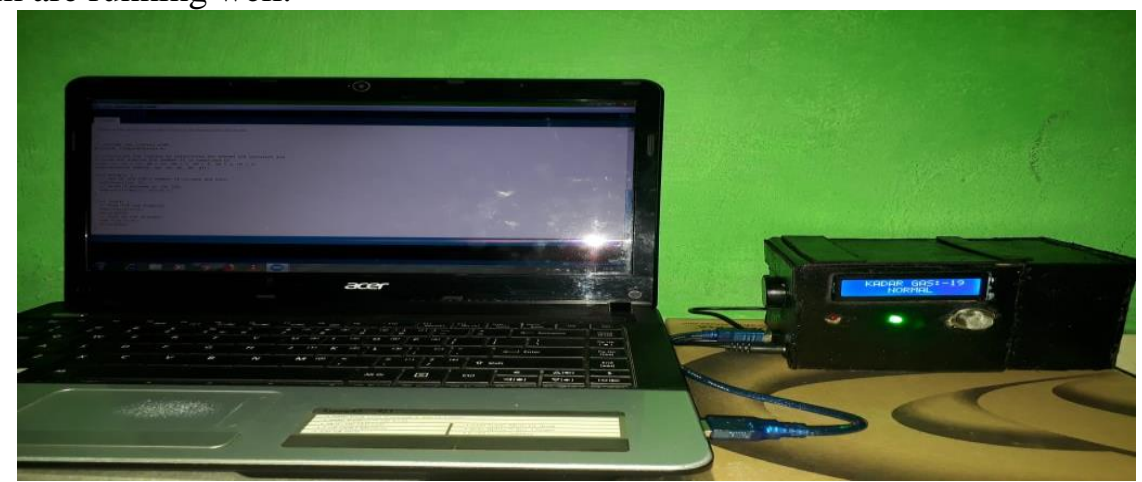

Figure 14. System Testing

In Figure 15 you can see the main parts installed on this device, namely:

1. MQ-6 gas sensor as a gas sensor.

2. Buzzer as a warning alarm if a leak occurs.

3. Speaker as a warning alarm if a leak occurs.

4. SMS as home ownership information in the event of a leak

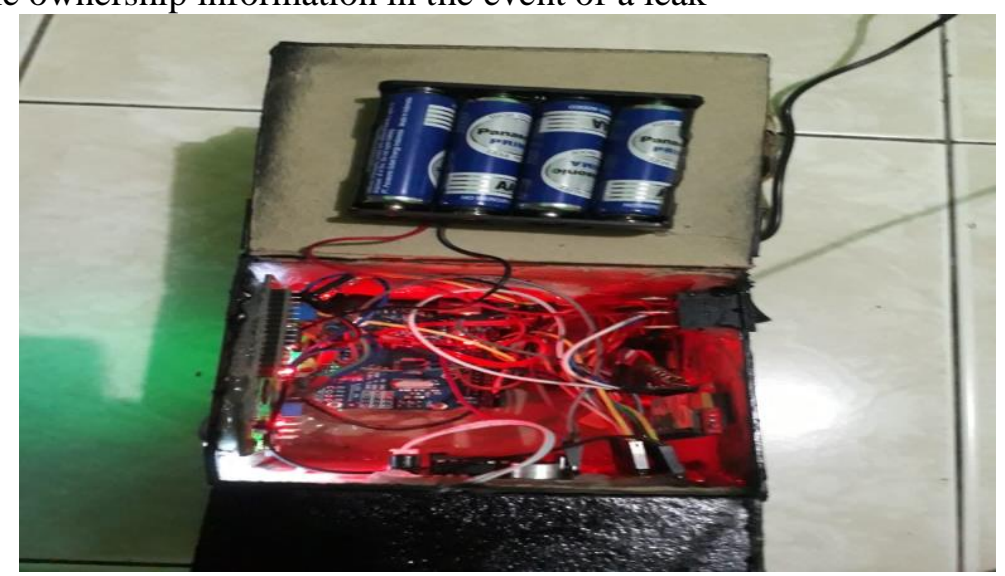

Figure 15. Installed Tools Series

When the microcontroller is working and the sensor is active, the LCD will display a serial gas sensor monitor to monitor the gas leak condition. The condition of the value of the gas leakage level is given if the value of the gas content is more than $100 \mathrm{ppm}$, then the MQ-6 sensor will read that a leak has occurred and will give a warning with the sound of the alarm, the sound of warning danger through speakers and SMS to the homeowner. If it does not detect a leak, the gas content value is equal to $0 \mathrm{ppm}$ to $-50 \mathrm{ppm}$. The algorithm of detecting gas content is to use the ppm unit. 


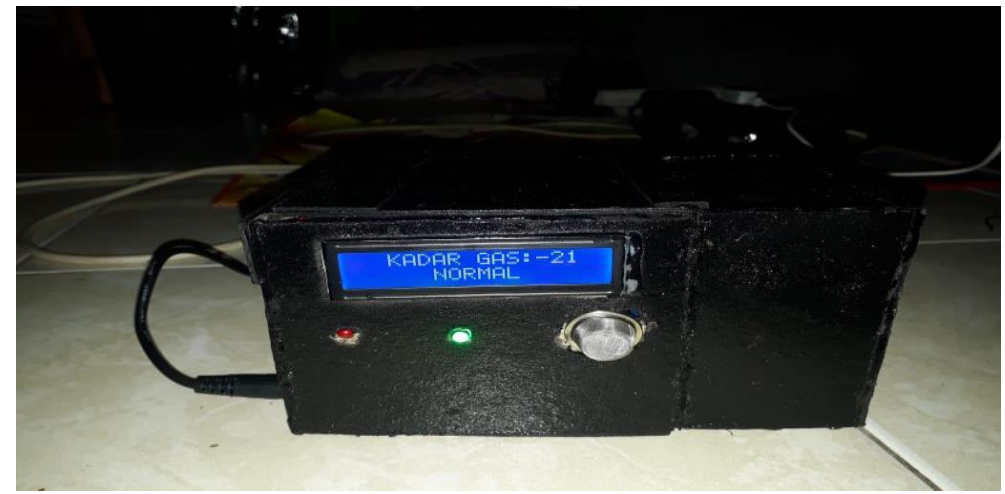

Figure 16. Total Gas Content (ppm)

The gas leak detection system that was built involves Arduino UNO, LCD display, serial port, buzzer, speakers, LED lights, and GSM as the sender of short messages. MQ6 is used because of the rapid response to methane, propane and butane when compared to similar sensors, buzzer is used as a warning alarm, LED lights are used as warning lights in the form of visualization of danger signals, speakers are used as sound warning sounds and SMS to the house if gas leak occurred. LCD display is used as a media display that the level of gas is detected in parts per million (ppm), serial port is used as a communication port connecting between Atmega 328 with GSM, GSM is used as a short message sending center.

\section{Testing of MQ-6 Gas Sensor}

This test was carried out 5 times in different distances which were carried out in 3 different places, namely ventilated space, airtight space and open space. Then the results of the test are recorded in the test table starting from the distance of the testing time of the test, the system response time to leakage and the amount of LPG levels that leak in ppm units.

\section{Testing in a ventilated room}

The test is carried out 5 times in the estimated time of testing for 15 seconds and also different distances, then the test results obtained are as presented in table 1 below.

Table 1. Test Results of Ventilated Room Gas Sensors

\begin{tabular}{ccccc}
\hline No. & Range & $\begin{array}{c}\text { Duration of Gas } \\
\text { Testing Time }\end{array}$ & Time to Detect & Detected Results \\
\hline 1. & $2 \mathrm{Cm}$ & 15 Seconds & 3 Seconds & $120 \mathrm{Ppm}$ \\
2. & $4 \mathrm{Cm}$ & 15 Seconds & 5 Seconds & $117 \mathrm{Ppm}$ \\
3. & $6 \mathrm{Cm}$ & 15 Seconds & 6 Seconds & $126 \mathrm{Ppm}$ \\
4. & $8 \mathrm{Cm}$ & 15 Seconds & 8 Seconds & $62 \mathrm{Ppm}$ \\
5. & $10 \mathrm{Cm}$ & 15 Seconds & 8 Seconds & $54 \mathrm{Ppm}$ \\
\hline
\end{tabular}

From the test results shown in table 4.1 that during the 15 -seconds test where the distance between the leak object and the detection device is relatively limited, different detection times are obtained and the amount of gas collection detected by the sensor is different. At a distance of $2 \mathrm{~cm}$, the time to detect a gas leak is only 3 seconds with a total gas content of $120 \mathrm{ppm}$, the amount of gas content obtained is much smaller when compared with testing at a distance of 6 $\mathrm{cm}$ where the gas content obtained is $126 \mathrm{ppm}$ with a time for detect only 6 seconds during the 15 second test. This could be due to the circulation of air that is at the test location, the air entering the room at the time of the test distance of $2 \mathrm{~cm}$ makes the concentration of methane gas disguised and decomposed so that the sensor only gets a gas density value of $120 \mathrm{ppm}$.

\section{Testing in an Airtight Room}

Just as in a test in a ventilated room, testing 5 times at an estimated time of 15 seconds and different test distances, the test results obtained are as presented in table 2 below.

Table 2. Test Results of Airtight Room Gas Sensors

\begin{tabular}{ccccc}
\hline No. & Range & $\begin{array}{c}\text { Duration of Gas } \\
\text { Testing Time }\end{array}$ & Time to Detect & Detected Results \\
\hline 1. & $2 \mathrm{Cm}$ & 15 Seconds & 3 Seconds & $457 \mathrm{Ppm}$
\end{tabular}




\begin{tabular}{ccccc} 
2. & $4 \mathrm{Cm}$ & 15 Seconds & 5 Seconds & $132 \mathrm{Ppm}$ \\
3. & $6 \mathrm{Cm}$ & 15 Seconds & 6 Seconds & $251 \mathrm{Ppm}$ \\
4. & $8 \mathrm{Cm}$ & 15 Seconds & 6 Seconds & $128 \mathrm{Ppm}$ \\
5. & $10 \mathrm{Cm}$ & 15 Seconds & 12 Seconds & $40 \mathrm{Ppm}$ \\
\hline
\end{tabular}

The results are shown in table 2 where the testing time is 15 seconds and the distance between the leak object and the detection system is relatively limited to obtain different detection times and the number of gas assemblies detected by different sensors. As shown in the comparison of testing at a distance of $10 \mathrm{~cm}$ and a distance of $2 \mathrm{~cm}$ where the density produced at a distance of $2 \mathrm{~cm}$ by $457 \mathrm{ppm}$ is greater with a detection time of 3 seconds than testing at a distance of $10 \mathrm{~cm}$ by $40 \mathrm{ppm}$ with the required time of 12 seconds. This could have been caused by air circulation which was not generated in a closed test room without ventilation.

\section{Testing in the open room}

The test is carried out 5 times in the estimated time of testing for 15 seconds and also different distances, then the test results obtained are as presented in table 3 below.

Table 3. Test Results of Open-Space Gas Sensors

\begin{tabular}{ccccc}
\hline No. & Range & $\begin{array}{c}\text { Duration of Gas } \\
\text { Testing Time }\end{array}$ & Time to Detect & Detected Results \\
\hline $\mathbf{1 .}$ & $2 \mathrm{Cm}$ & 15 Seconds & 13 Seconds & 6 Ppm \\
$\mathbf{2 .}$ & $4 \mathrm{Cm}$ & 15 Seconds & - & Not Detected \\
$\mathbf{3 .}$ & $6 \mathrm{Cm}$ & 15 Seconds & - & Not Detected \\
$\mathbf{4 .}$ & $8 \mathrm{Cm}$ & 15 Seconds & - & Not Detected \\
$\mathbf{5 .}$ & $10 \mathrm{Cm}$ & 15 Seconds & - & Not Detected \\
\hline
\end{tabular}

The results shown in table 3 where the duration of the test for 15 seconds and the distance between the leak object and the detection system between 2, 4, 6, 8, and $10 \mathrm{~cm}$ obtained the detected results only at a distance of $2 \mathrm{~cm}$ with a detection time of 13 seconds and an amount of $6 \mathrm{ppm}$, while from a distance of 4, 6, 8 and $10 \mathrm{~cm}$ no gas leak was detected.vFrom the test results it can then be concluded if the distance between the tool, object and place greatly influences the device in carrying out the detection. The closer the distance between the device and the censored object and the small air circulation, the faster the system will detect if there is a gas leak so it is very efficient to prevent fires due to gas leakage. An ideal distance to detect between $2 \mathrm{~cm}$ to $6 \mathrm{~cm}$ in a ventilated and airtight room. Then other factors that influence censorship are wind factors such as testing in open spaces, if the wind blows hard enough then the detected gas levels will decrease / not be detected.

\section{SMS Testing}

This test was carried out 5 times with 3 different places, as for the results of the test in the table and figure below.

\section{Testing SMS in a ventilated room}

Table 4. Test Results of Ventilated SMS Room

\begin{tabular}{cccccc}
\hline No. & $\begin{array}{c}\text { Sensor } \\
\text { Response }\end{array}$ & Gas Level & $\begin{array}{c}\text { Delivery time } \\
\text { SMS }\end{array}$ & Received SMS & $\begin{array}{l}\text { Provider } \\
\text { Server }\end{array}$ \\
\hline 1. & 3 Seconds & $120 \mathrm{ppm}$ & 8 Seconds & $\begin{array}{c}\text { LPG Gas Leak } \\
\text { Detected...!!! }\end{array}$ & Telkomsel \\
2. & 5 Seconds & $117 \mathrm{ppm}$ & 14 Seconds & $\begin{array}{c}\text { LPG Gas Leak } \\
\text { Detected...!! } \\
\text { LPG Gas Leak } \\
\text { Detected...!!! }\end{array}$ & Telkomsel \\
3. & 6 Seconds & $126 \mathrm{ppm}$ & 26 Seconds & - & Telkomsel \\
4. & 8 Seconds & $62 \mathrm{ppm}$ & - & - & Telkomsel \\
5. & 8 Seconds & $54 \mathrm{ppm}$ & - & & - \\
\hline
\end{tabular}




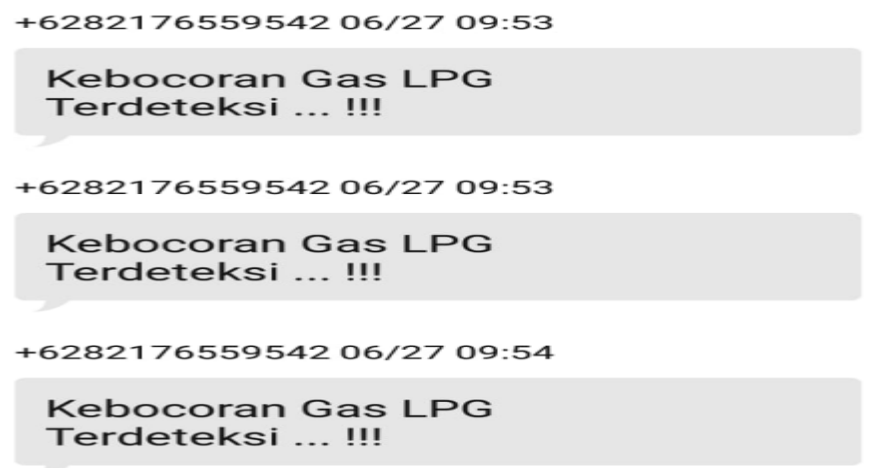

Figure 17. Testing SMS Ventilated Room

The test results are shown in table 4 . by testing the device 5 times where the SMS speed for the ventilated place is between 8-24 seconds with a testing distance of 2, 4 and $6 \mathrm{~cm}$. While at a distance of 8 and $10 \mathrm{~cm}$ no leaks were detected, because the detected gas levels were below $100 \mathrm{ppm}$.

\section{Testing SMS in an airtight room}

Table 5. Test Results of Airtight Room SMS

\begin{tabular}{cccccc}
\hline No. & $\begin{array}{c}\text { Sensor } \\
\text { Response }\end{array}$ & Gas Level & $\begin{array}{c}\text { Delivery } \\
\text { time } \\
\text { SMS }\end{array}$ & Received SMS & $\begin{array}{l}\text { Provider } \\
\text { Server }\end{array}$ \\
\hline 1. & 3 Seconds & $457 \mathrm{ppm}$ & 16 Seconds & $\begin{array}{c}\text { LPG Gas Leak } \\
\text { Detected..!!! } \\
\text { LPG Gas Leak } \\
\text { Detected...!! }\end{array}$ & Telkomsel \\
2. & 5 Seconds & $132 \mathrm{ppm}$ & 22 Seconds & $\begin{array}{c}\text { TPG Gas Leak } \\
\text { Detected...!!! }\end{array}$ & Telkomsel \\
3. & 6 Seconds & $251 \mathrm{ppm}$ & 182 Seconds & $\begin{array}{c}\text { LPG Gas Leak } \\
\text { Detected...!!! }\end{array}$ & Telkomsel \\
4. & 6 Seconds & $128 \mathrm{ppm}$ & 56 Seconds & - & Telkomsel \\
\hline 5. & 12 Seconds & $40 \mathrm{ppm}$ & - & &
\end{tabular}

Kebocoran Gas LPG

Terdeteksi ...!!!

Kebocoran Gas LPG

Terdeteksi ...!!!

Kebocoran Gas LPG

Terdeteksi ...!!!

Kebocoran Gas LPG

Terdeteksi ...!!!

Figure 18. Testing SMS in the Airtight Room

The test results are shown in table 5. by testing the device 5 times where the speed of the SMS to be airtight is between 16-182 seconds with a test distance of 2, 4, 6 and $8 \mathrm{~cm}$. While at a distance of $10 \mathrm{~cm}$ no leaks were detected, because the detected gas levels were below $100 \mathrm{ppm}$.

\section{Testing SMS in the open room}

Table 6. Test Results of Open Space SMS 


\begin{tabular}{cccccc}
\hline No. & $\begin{array}{c}\text { Sensor } \\
\text { Response }\end{array}$ & Gas Level & $\begin{array}{c}\text { Delivery time } \\
\text { SMS }\end{array}$ & Received SMS & $\begin{array}{l}\text { Provider } \\
\text { Server }\end{array}$ \\
\hline 1. & 13 Seconds & $6 \mathrm{ppm}$ & - & - & Telkomsel \\
2. & - & - & - & - & Telkomsel \\
3. & - & - & - & - & Telkomsel \\
4. & - & - & - & - & Telkomsel \\
5. & - & - & - & - & Telkomsel \\
\hline
\end{tabular}

The test results shown in table 6 with testing tools 5 times where the speed of SMS for the open place with a test distance of $2,4,6,8$ and $10 \mathrm{~cm}$ were not detected any leakage, because the detected gas levels below $100 \mathrm{ppm}$. From the test results above, it can be concluded if the gas leak has reached $100 \mathrm{ppm}$, then the message will be sent to the destination number, the speed of arrival of the message to the destination number ranges from $8-182$ seconds. The speed of SMS received also depends on the location or architecture of the cellular network of each provider.

\section{CONCLUSIONS}

Based on the whole system starting from the design and manufacture of tools that have been done, the author has several conclusions including :

1. Sensor testing is carried out in three different places, namely ventilated space, airtight space, and open space. In the test room ventilated results of the detected gas content between $54-126 \mathrm{ppm}$, in the airtight room the detected results were between $40-457$ $\mathrm{ppm}$, and in the open room the detected results were only $6 \mathrm{ppm}$.

2. Distance testing of the MQ-6 sensor is performed at a distance of $2 \mathrm{~cm}, 4 \mathrm{~cm}, 6 \mathrm{~cm}, 8 \mathrm{~cm}$ and $10 \mathrm{~cm}$. It was also carried out in three different places, from the test the ideal distance for detection is at a distance of 2 to $6 \mathrm{~cm}$ in a ventilated and airtight room. Then other factors that influence censorship are wind factors such as testing in open spaces, if the wind blows hard enough then the detected gas levels will decrease / not be detected.

3. SMS testing is also carried out in three different places, namely ventilated space with sensor response time between 3 to 8 seconds and SMS sending time between 8 to 26 seconds, airtight space with sensor response time 3 to 12 seconds and SMS sending time between 16 to 182 seconds, while in the open space the sensor response time is only 13 seconds and no texting is detected because there are no leaks with amounts of gas above $100 \mathrm{ppm}$.

\section{REFERENCES}

Elasya, Y. (2016). APLIKASI SENSOR ULTRASONIK BERBASIS MIKROKONTROLER ATMEGA328 UNTUK MERANCANG TEMPAT SAMPAH PINTA. Jurnal Online Mahasiswa (JOM) Bidang Teknik Elektro, 1(1).

Fatoni, A., \& Rendra, D. B. (2014). Perancangan Prototype Sistem Kendali Lampu Menggunakan Handphone Android Berbasis Arduino. PROSISKO: Jurnal Pengembangan Riset dan Observasi Sistem Komputer, 1.

Hakim, L., \& Yonatan, V. (2017). Deteksi Kebocoran Gas LPG menggunakan Detektor Arduino dengan algoritma Fuzzy Logic Mandani. Jurnal RESTI (Rekayasa Sistem dan Teknologi Informasi), 1(2), 114-121.

Hendini, A. (2016). Pemodelan UML sistem informasi monitoring penjualan dan stok barang (studi kasus: distro zhezha pontianak). Jurnal Khatulistiwa Informatika, 4(2).

Kadir, A. (2018). Arduino and Sensor. Yogyakarta: ANDI.

Ohoiwutun, J. (2018). Analysis and Design of Smart Dump Using Arduino Mega 2560 Rev3 and GSM Sim900. Electro Luceat, Vol. 4 No.1, 4.

Putra, M. F., Kridalaksana, A. H., \& Arifin, Z. (2017). Rancang Bangun Alat Pendeteksi Kebocoran Gas LPG Dengan Sensor Mq-6 Berbasis Mikrokontroler Melalui Smartphone Android Sebagai Media Informasi.

Wiyono, A., Sudrajat, A., Rahmah, F., \& Darusalam U. (2017). Rancang Bangun Sistem 
Deteksi Dan Pengaman Kebocoran Gas Berbasis Algoritma Bahasa C Dengan Menggunakan Sensor Mq-6. KOMIK (Konferensi Nasional Teknologi Informasi dan Komputer), 1(1), Oktober 2017. 